\title{
PENGARUH PRODUK DOMESTIK REGIONAL BRUTO, PENDAPATAN ASLI DAERAH DAN DANA ALOKASI UMUM TERHADAP BELANJA MODAL DI KOTA BALIKPAPAN
}

\author{
Hariani Dwi Hartati \\ RSUD Dr. Kanujoso Djatiwibowo Balikpapan \\ E-mail: perpusmsi.unmul@gmail.com
}

\begin{abstract}
This project was designed to: 1) explore the effects of Gross Domestic Product (GDP), Own-source Revenue (PAD), and government transfer payments to local capital expenditures, both partially and simultaneously; 2) find out the dominant variable which affected the local capital expenditure in Balikpapan. The data, which was obtained through literature review study, were in the type of secondary and time series records derived during the period of 2002-2011. Further, these files were analyzed by implementing multiple linear regressions with three predictors technique, where the assumption tests was applied earlier presently before the main analysis. Eventually, the results showed that: 1) GDP, Local Revenue and government transfer payments gave significant impact on local capital expenditures of Balikpapan simultaneously. a) GDP has considerable effect on local capital expenditures partially; $b$ ) local revenue has not extensively influence the local capital expenditure to some extent; c) the government transfer payments has not much influence on the local capital expenditure in some measure. 2) GDP was the most dominant variable affecting the local capital expenditures.
\end{abstract}

Keywords: Capital Expenditure, Gross Domestic Product, Local Revenue, Government Transfer Payments

\begin{abstract}
Abstrak
Penelitian ini bertujuan untuk: 1) menganalisis efek PDB, PAD dan transfer pemerintah untuk belanja modal lokal, baik secara parsial dan simultan; 2) mengetahui variabel yang dominan mempengaruhi belanja modal lokal Kota Balikpapan. Data yang digunakan adalah skunder dan time series tahun 2002-2011. Metode pengumpulan data menggunakan metode penelitian kepustakaan. Teknik analisis data yang digunakan regresi linier berganda dengan menggunakan tiga prediktor, dimana tes asumsi yang diterapkan sebelum analisis utama. Hasil analisis menunjukan bahwa: 1) PDB, Pendapatan Daerah, dan transfer pemerintah memiliki pengaruh yang signifikan terhadap belanja modal lokal Kota Balikpapan secara bersamaan. a) PDB memiliki pengaruh yang signifikan terhadap belanja modal lokal sebagian; $b$ ) pendapatan lokal belum berpengaruh signifikan terhadap belanja modal lokal sebagian; c) Transfer Pemerintah belum berpengaruh signifikan terhadap belanja modal lokal sebagian. 2) PDB merupakan variabel yang paling dominan mempengaruhi belanja modal lokal.
\end{abstract}

Kata kunci: Pengeluaran Modal, Produk Domestik Bruto, Pendapatan Daerah, Transfer Pemerintah 
Paradigma pengelolaan keuangan daerah telah mengalami perubahan yang sangat mendasar sejak diterapkannya otonomi daerah pada tahun 2001. Dengan diberlakukannya Undang-undang No. 22 Tahun 1999 (kemudian menjadi UU No.32 Tahun 2004) tentang Pemerintahan Daerah dan Undang-undang Nomor 25 Tahun 1999 (kemudian menjadi UU No. 33 Tahun 2004) tentang Perimbangan Keuangan antara Pemerintah Pusat dan Daerah), menjadi landasan utama dalam pelaksanaan otonomi daerah (Mahmudin, 2009: 2).

Hal-hal yang mendasar dalam undang-undang ini adalah kuatnya upaya untuk mendorong pemberdayaan masyarakat, pengembangan prakarsa dan kreativitas, peningkatan peran serta masyarakat, dan pengembangan peran dan fungsi DPRD. UU ini memberikan otonomi secara utuh kepada daerah kabupaten dan kota untuk membentuk dan melaksanakan kebijakan menurut prakarsa dan aspirasi masyarakatnya, artinya, saat sekarang daerah sudah diberi kewenangan yang utuh dan bulat untuk merencanakan, melaksanakan, mengawasi, mengendalikan dan mengevaluasi kebijakan-kebijakan daerah (Mardiasmo, 2009: 63).

Kewenangan tersebut dipertegas dan diatur dalam UU No. 32 Tahun 2004 tentang Pemerintahan Daerah. Dalam UU No.32 Tahun 2004 dijelaskan bahwa otonomi daerah menggunakan prinsip otonomi seluas-luasnya dalam arti daerah diberikan kewenangan mengurus dan mengatur semua urusan pemerintahan di luar urusan pemerintah pusat yang ditetapkan dalam undang-undang tersebut.

Untuk mewujudkan pengelolaan keuangan daerah yang ekonomis, efisien dan efektif pemerintah daerah perlu menerapkan prinsip-prinsip manajemen keuangan daerah secara cermat, konsisten dan berkelanjutan, Terdapat tiga pilar utama yang menopang keberhasilan manajemen keuangan publik, yaitu manajemen pendapatan, manjemen belanja dan manajemen pembiayaan. Pengetahuan dan keahlian tentang manajemen pendapatan bagi manajer publik sangat penting karena besar kecilnya pendapatan akan menentukan tingkat kualitas pelaksanaan pemerintahan, tingkat kemampuan pemerintah dalam penyediaan pelayanan publik serta keberhasilan pelaksanaan program dan kegiatan pembangunan. Pemerintah dituntut untuk cerdas dalam menghasilkan dan mengelola sumber-sumber pendapatann. Hal inilah yang oleh Osborne dan Gaebler (1992) dikatakan sebagai pemerintahan yang berwirausaha (entrepreneurial government).

Salah satu elemen dalam pembelanjaan APBD adalah belanja modal, (capital expenditure), yaitu pengeluaran anggaran untuk perolehan aset tetap dan aset lainnya yang memberi manfaat lebih dari satu periode akuntasi. Belanja modal meliputi antara lain belanja modal untuk perolehan tanah, gedung dan bangunan, peralatan, aset tak berwujud. Elemen belanja daerah ini sering menjadi sorotan publik.

Untuk membiayai belanja modal tersebut diperlukan sumber pendapatan daerah. Dengan belanja yang semakin meningkat maka dibutuhkan dana yang besar pula agar belanja untuk kebutuhan pemerintah daerah dapat terpenuhi. Dengan terpenuhinya kebutuhan belanja pemerintah maka diharapkan pelayanan terhadap masyarakat menjadi lebih baik dan kesejahteraan masyarakat menjadi meningkat. 
Berdasarkan pasal 5 UU No. 33 tahun 2004 sumber-sumber penerimaan daerah adalah pendapatan daerah dan pembiayaan. Pendapatan daerah terdiri dari Pendapatan Asli Daerah (PAD), dana perimbangan dan lain-lain pendapatan. Dana Perimbangan Keuangan PusatDaerah merupakan mekanisme transfer pemerintah pusat-daerah terdiri dari Dana Bagi Hasil Pajak dan Sumber Daya Alam (DBHP dan SDA), Dana Alokasi Umum (DAU), dan Dana Alokasi Khusus (DAK). Dana pembiayaan daerah berasal dari Sisa Lebih Anggaran daerah (SAL), pinjaman daerah, dana cadangan daerah dan privatisasi kekayaan daerah yang dipisahkan.

Dalam hal membiayai belanja daerah, dikarenakan setiap daerah mempunyai kemampuan keuangan yang tidak sama dalam mendanai kegiatan-kegiatannya, maka menimbulkan ketimpangan fiskal antara satu daerah dengan daerah lainnya. Oleh karena itu, untuk mengatasi ketimpangan fiskal ini Pemerintah mengalokasikan dana yang bersumber dariAPBN untuk mendanai kebutuhan daerah dalam pelaksanaan desentralisasi. Salah satu dana perimbangan dari pemerintah ini adalah Dana Alokasi Umum(DAU) yang pengalokasiannya menekankan aspek pemerataan dan keadilan yang selaras dengan penyelenggaraan urusan pemerintahan (UU 32/ 2004). Dengan adanya transfer dana dari pusat ini diharapkan pemerintah daerah bisa mengalokasikan dana transfer yang didapatnya untuk membiayai belanja di daerahnya termasuk belanja modal.

Dalam teori ekonomi pembangunan, pertumbuhan ekonomi dan pengeluaran pemerintah (government expenditure) mempunyai hubungan timbal balik yang positif. Wagner menyebutkan bahwa dalam suatu perekonomian apabila pertumbuhan ekonomi meningkat maka pengeluaran pemerintah juga akan meningkat (Wagner dalam Mahyuddin, 2009), dimana analogi untuk Hukum Wagner ini adalah dengan meningkatnya pertumbuhan ekonomi maka kebutuhan akan penyediaan barang publik juga akan meningkat sehingga dibutuhkan pembiayaan melalui penerimaan pemerintah yang pada akhirnya pengeluaran pemerintah juga akan meningkat atau dapat diartikan pertumbuhan ekonomi yang tinggi juga akan mencerminkan besarnya dana pengeluaran pemerintah untuk membiayai kebutuhan layanan jasa pemerintah.

Konsep tersebut dikatakan oleh Wagner sebagai berikut: 'as per capita income rises in industrialising nations, their public sectors will grow in relative importance' (Peters, 2011: 5). Teori tersebut didukung oleh Peacock dan Wiseman: "bahwa perkembangan ekonomi menyebabkan pemungutan pajak yang semakin meningkat walaupun tarif pajak tidak berubah; dan meningkatnya penerimaan pajak menyebabkan pengeluaran pemerintah juga semakin meningkat. Oleh karena itu, dalam keadaan normal, meningkatnya GNP menyebabkan penerimaan pemerintah yang semakin besar, begitu juga dengan pengeluaran pemerintah menjadi semakin besar" (Mangkoe-soebroto, 1993: 173).

Hipotesis yang dikemukakan oleh Wagner tersebut di atas menggunakan Produk Domestik Bruto (PDB) (GDP/ Gross Domestic Produtc) sebagai dasar penghitungan. Dengan demikian maka seiring dengan meningkatnya PDB maka seharusnya belanja pemerintah semakin meningkat pula.

Kenyataan di lapangan menunjukkan hal yang berbeda di Kota Balikpapan. Pen- 
dapatan Asli Daerah (PAD) Kota Balikpapan dari tahun ke tahun semakin meningkat tetapi bagian terbesar pendapatan daerah masih didominasi oleh dana perimbangan (terutama Dana Bagi Hasil dan Dana Alokasi Umum). Ini menunjukkan bahwa peningkatan kemandirian daerah belum signifikan.

Hasil pengamatan terhadap Produk Domestik Bruto (PDRB) Kota Balikpapan selama periode 2002-2011 menunjukkan bahwa PDRB mengalami peningkatan yang cukup signifikan dari tahun ke tahun. Hal ini ditunjukkan dengan data PDRB tahun 2002 sebesar Rp. 13,387 trilyun yang meningkat hingga mencapai Rp. 45,128 trilyun. Ratarata kenaikan PDRB setiap tahunnya berkisar sekitar $15.20 \%$. Penurunan PDRB hanya terjadi pada tahun 2009, yaitu dari sebesar Rp. 38,527 trilyun pada tahun 2008 menjadi Rp. 36,521 trilyun atau turun sebesar $5.21 \%$.

Adapun dalam hal total pendapatan daerah, hasil pengamatan terhadap data statistik selama periode 2002-2011 menunjukkan bahwa total pendapatan daerah Kota Balikpapan selama Periode 2002 2011 cenderung meningkat. Hal ini ditunjukkan dengan data total pendapatan daerah pada tahun 2002 baru mencapai Rp. 486,252 milyar, kemudian meningkat hingga mencapai Rp. 1,637 trilyun pada tahun 2011. Rata-rata kenaikan pendapatan daerah berkisar sekitar $15.81 \%$. Penurunan pendapatan hanya terjadi pada tahun 2004 dan 2012, yaitu mengalami penurunan sebesar $1.72 \%$ pada tahun 2004 , dan $12.13 \%$ pada tahun 2010 .

Meningkatnya pendapatan daerah di Kota Balikpapan selama periode 2002 2011 diiringi dengan meningkatnya pembelanjaan daerah. Hal ini ditunjukkan dengan besarnya pembelanjaan daerah pada tahun 2002 sebesar Rp. 422,969 milyar, kemudian meningkat hingga mencapai Rp. 1,637 trilyun pada tahun 2011.

Menurut teori Wagner, yang menyatakan bahwa bahwa pengeluaran pemerintah dan kegiatan pemerintah semakin lama semakin meningkat. Tendensi ini oleh Wagner disebut dengan hukum selalu meningkatnya peranan pemerintah. Inti teorinya yaitu makin meningkatnya peran pemerintah dalam kegiatan dan kehidupan ekonomi masyarakat sebagai suatu keseluruhan. Wagner menyatakan bahwa dalam suatu perekonomian apabila pendapatan per kapita meningkat maka secara relatif pengeluaran pemerintah pun akan meningkat terutama disebabkan karena pemerintah harus mengatur hubungan yang timbul dalam masyarakat, hukum, pendidikan, rekreasi, kebudayaan dan sebagainya (Peters, 2011: 6).

Belanja daerah sangat dipengaruhi oleh kondisi keuangan daerah dan kemampuan daerah dalam menggali sumber-sumber keuangan sendiri serta transfer dari pusat. Kemampuan daerah Kota Balikpapan dalam menggali sumber keuangan yang ditunjukkan dengan besarnya PAD yang besaran rata-ratanya mencapai $10.31 \%$ dari total pendapatan daerah.

Ssebagai dasar sekaligus acuan dalam mengerjakan penelitian ini digunakan beberapa hasil penelitian terdahulu yang relevan dengan penelitian yang akan lakukan, berikut adalah beberapa penelitian yang dapat dijadikan acuan serta perbandingan dalam pengerjaan penelitian ini.

Ikin Solikin (2007) melakukan penelitian dengan judul "Hubungan Pendapatan Asli Daerah (PAD), Dana Alokasi Umum (DAU) dan Belanja Modal di Jawa Barat tahun 2007'. Hasil penelitian 
Pengaruh Produk Domestik Regional Bruto... (Hariani Dwi Hartati)

menyimpulkan bahwa PAD dan DAU mempunyai hubungan positif yang kuat terhadap Belanja Modal.

Askam Tuasikal (2008) melakukan penelitian tentang Pengaruh DAU, DAK, PAD dan PDRB terhadap Belanja Modal Pemerintah Kabupaten/ Kota di Indonesia tahun anggaran 2005. Hasilnya: bahwa secara simultan DAU, DAK, PAD dan PDRB berpengaruh terhadap Melanja modal pemerintah daerah kabupaten/kota di Indonesia. Secara parsial menunjukkan bahwa DAU, DAK, dan PAD berpengaruh postif terhadap alokasi Belanja Modal daerah kabupaten/kota di Indonesia pada tahun anggaran 2005. Sementara PDRB tidak berpengaruh.

Farah Marta Yovita (2011) melakukan studi empiris pada Pemerintah Provinsi se Indonesia: tahun 2008 sampai dengan tahun 2010 tentang Pengaruh Pertumbuhan Ekonomi, Pendapatan Asli Daerah dan Dana Alokasi Umum terhadap pengalokasian Belanja Modal. Hasilnya Pertumbuhan ekonomi yang diproksikan ke dalam Produk Domestik Regional Bruto (PDRB) berpengaruh signifikan positif terhadap Belanja Modal dan Dana Alokasi Umum berpengaruh signifikan negatif terhadap Belanja Modal sedangkan Pendapatan Asli Daerah tidak berpengaruh signifikan terhadap alokasi Belanja Modal pada Pemerintah Provinsi se Indonesia tahun 2008 - 2010.

Nugroho Suratno Putro (2011) melakukan penelitian tentang Pengaruh Pertumbuhan Ekonomi, Pendapatan Asli Daerah dan Dana Alokasi Umum terhadap Belanja Modal (Study Kasus pada Kabupaten/Kota di Provinsi Jawa Tengah) Tahun 2004 - 2006. Hasilnya adalah: Dana Alokasi Umumberpengaruh signifikan ter- hadap Pengalokasian Anggaran Belanja Modal. Sedangkan Pertumbuhan Ekonomi dan Pendapatan Asli Daerah tidak berpengaruh signifikan terhadap pengalokasian anggaran Belanja Modal.

Rini Oktriniatmaja (2011) melakukan penelitian tentang Pengaruh Pendapatan Asli Daerah, Dana Alokasi Umum, Dana Alokasi Khusus terhadap Pengalokasian Belanja Modal Anggaran Pendapatan dan Belanja Daerah pada Pemerintah Daerah Kabupaten / Kota di Pulau Jawa, Bali dan Nusa Tenggara Tahun 2004-2008. Hasilnya adalah: Pendapatan Asli Daerah, Dana Alokasi Umum dan Dana Alokasi Khusus berpengaruh positif terhadap alokasi Belanja Modal baik secara parsial maupun secara simultan.

Mohammed Al Bataineh (2012) melakukan penelitian dengan judul "The Impact of Government Expenditures on Economic Growth in Jordan". Penelitian yang dilakukan oleh Al Bataineh bertujuan untuk mengkaji dampak pembelanjaan publik terhadap pertumbuhan ekonomi di Yordania. Penelitian dilakukan dengan menggunakan data rangkaian waktu periode antara 1990-2010. Pertumbuhan ekonomi diukur dengan menggunakan Gross Domestic Product (GDP), sedangkan pembelanjaan pemerintah ditinjau dari pembelanjaan rutin (recurring expenditure), belanja modal (capital expenditure), biaya transfer (transfer payment), dan biaya bunga (interest payment). Analisis data dilakukan dengan menggunakan analisis regresi.

Penelitian yang dilakukan olehAlexiou (2009) berjudul "Government Spending and Economic Growth: Econometric Evidence from the South Eastern Europe (SEE)". Penelitian yang dilakukan oleh 
Alexiou bertujuan untuk mengkaji keterkaitan antara pembelanjaan pemerintah dengan pertumbuhan ekonomi di negara-negara Eropa Tenggara. Penelitian dilakukan dengan menggunakan data panel dengan rentang waktu periode antara 1995 - 2005. Teknik analisis data dilakukan menggunakan OLS (Ordinary Least Square). Hasil penelitian menyimpulkan bahwa pembelanjaan pemerintah berkaitan erat dengan pertumbuhan ekonomi di negara-negara Eropa Tenggara.

Definisi keuangan negara menurut UU no. 17 tahun 2003 adalah sebagai berikut: Keuangan Negara adalah semua hak dan kewajiban negara yang dapat dinilai dengan uang, serta segala sesuatu baik berupa uang maupun berupa barang yang dapat dijadikan milik negara berhubung dengan pelaksanaan hak dan kewajiban tersebut.

Pendekatan yang digunakan dalam merumuskan definisi keuangan negara tersebut adalah dari sisi obyek, subyek, proses, dan tujuan. Dari sisi obyek yang dimaksud dengan keuangan negara meliputi semua hak dan kewajiban negara yang dapat dinilai dengan uang, termasuk kebijakan dan kegiatan dalam bidang fiskal, moneter dan pengelolaan kekayaan negara yang dipisahkan, serta segala sesuatu baik berupa uang, maupun berupa barang yang dapat dijadikan milik negara berhubung dengan pelaksanaan hak dan kewajiban tersebut.

Dari sisi subyek yang dimaksud dengan keuangan negara meliputi seluruh obyek sebagaimana tersebut di atas yang dimiliki negara, dan/atau dikuasai oleh Pemerintah Pusat, Pemerintah Daerah, Perusahaan Negara/Daerah, dan badan lain yang ada kaitannya dengan keuangan negara.
Dari sisi proses, keuangan negara mencakup seluruh rangkaian kegiatan yang berkaitan dengan pengelolaan obyek sebagaimana tersebut di atas mulai dari perumusan kebijakan dan pengambilan keputusan sampai dengan pertanggung jawaban.

Dari sisi tujuan, keuangan negara meliputi seluruh kebijakan, kegiatan dan hubungan hukum yang berkaitan dengan pemilikan dan/atau penguasaan obyek sebagaimana tersebut di atas dalam rangka penyelenggaraan pemerintahan negara.

Bidang pengelolaan keuangan negara yang luas tersebut dapat dikelompokkan ke dalam: (1) Sub bidang pengelolaan fiskal, (2) Sub bidang pengelolaan moneter, dan (3) Sub bidang pengelolaan kekayaan negara yang dipisahkan.

Dalam rangka mendukung terwujudnya good governance dalam penyelenggaraan negara, pengelolaan keuangan negara perlu diselenggarakan secara profesional, terbuka, dan bertanggung jawab sesuai dengan aturan pokok yang telah ditetapkan dalam Undang-Undang Dasar 1945. Aturan pokok Keuangan Negara telah dijabarkan ke dalamasas-asas umum, yang meliputibaik asas-asas yang telah lama dikenal dalam pengelolaan keuangan negara, seperti asas tahunan, asas universalitas, asas kesatuan, dan asas spesialitas maupun asas-asas baru sebagai pencerminan penerapan kaidah-kaidah yang baik (best practices) dalam pengelolaan keuangan negara.

Keuangan Daerah adalah semua hak dan kewajiban daerah dalam rangka penyelenggaraan pemerintahan daerah yang dapat dinilai dengan uang termasuk didalamnya segala bentuk kekayaan yang berhubungan dengan hak dan kewajiban daerah tersebut. Pengertian keuangan daerah sebagaimana 
dimuat dalam penjelasan pasal 156 ayat 1 Undang-Undang Nomor 32 Tahun 2004 tentang Pemerintahan Daerah adalah sebagai berikut:

"Keuangan daerah adalah semua hak dan kewajiban daerah yang dapat dinilai dengan uang dan segala sesuatu berupa uang dan barang yang dapat dijadikan milik daerah yang berhubungan dengan pelaksanaan hak dan kewajiban tersebut".

Ruang lingkup keuangan daerah meliputi: a) Hak daerah untuk memungut pajak daerah dan retribusi daerah serta melakukan pinjaman; b) Kewajiban daerah untuk menyelenggarakan urusan pemerintahan daerah dan membayar tagihan pihak ketiga; c) Penerimaan daerah; d) Pengeluaran daerah; e) Kekayaan daerah yang dikelola sendiri atau oleh pihak lain berupa uang, surat berharga, piutang, barang, serta hak-hak lain yang dapat dinilai dengan uang, termasuk kekayaan yang dipisahkan pada perusahaan daerah; dan f) Kekayaan pihak lain yang dikuasai oleh pemerintah daerah dalam rangka penyelenggaraan tugas pemerintahan daerah dan/atau kepentingan umum.

Menurut PP Nomor 71 Tahun 2010, belanja modal merupakan belanja Pemerintah Daerah yang manfaatnya melebihi 1 tahun anggaran dan akan menambah aset atau kekayaan daerah dan selanjutnya akan menambah belanja yang bersifat rutin seperti biaya pemeliharaan pada kelompok belanja administrasi umum. Belanja modal digunakan untuk memperoleh aset tetap pemerintah daerah seperti peralatan, infrastruktur, dan harta tetap lainnya. Cara mendapatkan belanja modal dengan membeli melalui proses lelang atau tender.

Sedangkan menurut PSAP Nomor 2, Belanja Modal adalah pengeluaran ang- garan untuk perolehan asset tetap dan asset lainnya yang memberi manfaat lebih dari satu periode akuntansi. Selanjutnya pada pasal 53 ayat 2 Permendagri Nomor 59 Tahun 2007 ditentukan bahwa nilai asset tetap berwujud yang dianggarkan dalambelanja modal sebesar harga beli/bangun asset ditambah seluruh belanja yang terkait dengan pengadaan/ pembangunan asset sampai asset tersebut siap digunakan. Kemudian pada pasal 53 ayat 4 Permendagri Nomor 59 Tahun 2007 disebutkan bahwa Kepala Daerah menetapkan batas minimal kapitalisasi sebagai dasar pembebanan belanja modal selain memenuhi batas minimal juga pengeluaran anggaran untuk belanja barang tersebut harus memberi manfaat lebih satu periode akuntansi bersifat tidak rutin.

Ketentuan hal ini sejalan dengan PP 24 Tahun 2004 tentang Standar Akuntansi Pemerintahan khususnya PSAP No 7, yang mengatur tentang akuntansi asset tetap. Belanja modal merupakan pengeluaran anggaran yang digunakan dalam rangka memperoleh atau menambah asset tetap dan asset lainnya yang memberikan manfaat lebih dari satu periode akuntansi serta melebihi batasan minimal kapitalisasi asset tetap atau asset lainnya yang ditetapkan pemerintah.

Menurut Halim (2004:73), belanja modal merupakan belanja Pemerintah Daerah yang manfaatnya melebih satu tahun anggaran dan akan menambah asset atau kekayaan daerah dan selanjutnya akan menambah belanja yang bersifat rutin seperti biaya pemeliharaan pada kelompok belanja administrasi umum. Belanja modal dapat juga disimpulkan sebagai pengeluaran yang dilakukan dalam rangka pembentukan modal yang sifatnya menambah asset tetap/ inventaris yang memberikan manfaat lebih 
dari satu periode akuntansi, termasuk didalamnya adalah pengeluaran untuk biaya pemeliharaan yang sifatnya mempertahankan atau menambah masa manfaat, rneningkatkan kapasitas dan kualitas asset.

Definisi tersebut senada dengan definisi yang dikemukakan oleh IMF bahwa capital spending adalah "generally about physical assets with a useful life of more than one year'. Selain itu, capital spending juga mencakup "capital improvements or the rehabilitation of physical assets that enhance or extend the useful life of the asset (as distinct from repair or maintenance, which assures that the asset is functional for its planned life)" (Jacobs, 2009).

Produk Domestik Regional Bruto (PDRB) merupakan data statistik yang merangkum perolehan nilai tambah dari seluruh kegiatan ekonomi disuatu wilayah pada satu periode tertentu. PDRB dihitung dalam dua cara, yaitu atas dasar harga berlaku dan atas dasar harga konstan. Dalam menghitung PDRB atas dasar harga berlaku menggunakan harga barang dan jasa tahun berjalan, sedangkan pada PDRB atas dasar harga konstan menggunakan harga pada suatu tahun tertentu (tahun dasar).

Perhitungan PDRB atas dasar harga konstan saat ini menggunakan tahun 2000 sebagai tahun dasar. Penggunaan tahun dasar ini ditetapkan secara nasional dan didefinisikan berdasarkan tiga pendekatan produksi, pendapatan dan pengeluaran (Indikator Makro Ekonomi, Pandeglang 2007).

Pendekatan Produksi (Production Approach). PDRB adalah jumlah nilai tambah bruto (NTB) yang tercipta sebagai hasil proses produksi barang dan jasa yang dilakukan oleh berbagai unit produksi dalam suatu wilayan/region pada suatu jangka waktu tertentu, biasanya setahun.

Rumus umum yang digunakan adalah

PDRB $=$ NTB Sektor $1+\ldots \ldots+$ NTB Sektor 9

sebagai berikut:

Pendekatan Pendapatan (Income Approach). PDRB adalah jumlah balas jasa yang diterima oleh faktor-faktor produksi yang ikut di dalam proses produksi disuatu wilayah/region pada jangka waktu tertentu (biasanya setahun). Balas jasa faktor tersebut adalah upah dan gaji, sewa tanah, bunga modal dan keuntungan. Termasuk sebagai komponen penyusun PDRB adalah penyusutan barang modal tetap dan barang modal tidak langsung neto. Jumlah semua komponen pendapatan ini persektor disebut sebagai nilai tambah bruto sektoral. PDRB merupakan jumlah dari nilai tambah bruto seluruh sektor (lapangan usaha).

Rumus umum untuk PDB dengan pendekatan pengeluaran adalah sebagai berikut:

$\mathrm{PDB}=\underline{\text { sewa }}+\underline{\text { upah }}+\underline{\text { bunga }}+\underline{\text { laba }}$

Pendekatan Pengeluaran (Expenditure Approach). PDRB adalah jumlah semua pengeluaran untuk konsumsi rumah tangga dan lembaga swasta yang tidak mencari untung, konsumsi pemerintah, pembentukan modal tetap domestik bruto, perubahan inventori, dan ekspor neto di suatu wilayah pada suatu periode (biasanya setahun).

Rumus umum untuk PDB dengan pendekatan pengeluaran adalah sebagai berikut:

$\mathrm{PDB}=\underline{\text { konsumsi }}+\underline{\text { investasi }}+\underline{\text { pengeluaran }}$ pemerintah $+($ ekspor $-\underline{\text { impor }})$ 
Dalam analisis Keuangan Negara, model-model tradisional menyatakan bahwa baik pengeluaran maupun penerimaan pemerintah ditentukan secara simultan sebagai "kemurahan hati pemerintah" (benevolent government) dalam upaya pemerintah untuk memaksimalkan fungsi kesejahteraan masyarakatnya (social welfare fuction) (Cullis dan Jones, 1994). Aliran teori yang berbeda-beda mengenai interdependensi antara kedua variabel tersebut berawal dari debat antara hipotesis pajak dan pengeluaran (tax and spend) dengan pengeluaran dan pajak (spend and $\operatorname{tax})$.

Belanja daerah mempengaruhi Produk Domestik Bruto (PDRB). John Due (1968) mengemukakan bahwa pemerintah dapat mempengaruhi tingkat PDRB dengan mengubah persediaan berbagai faktor yang dapat dipakai dalam produksi melalui program-program pengeluaran belanja pemerintah seperti pendidikan. Sementara Atep Adya Barata (2004) mengatakan bahwa kegiatan yang dilakukan pemerintah yang mendorong besaran jumlah pengeluaran negara mempunyai pengaruh terhadap perekonomian masyarakat. Sehingga hal ini menunjukan peningkatan belanja daerah akan meningkatkan PDRB.

Apabila PDRB meningkat maka akan berdampak kepada peningkatan kegiatan ekonomi, utamanya disektor riil dan dunia usaha pada umumnya. Peningkatan kegiatan ekonomi akan membawa pengaruh meningkatkan penerimaan pemerintah melalui perpajakan, karena bergairahnya perekonomian sehingga aktivitas dunia usaha meningkat dan pada akhirnya keuntungan perusahaan meningkat pula. Peningkatan aktivitas dan keuntungan perusahaan ini tentunya akan meningkatkan pemungutan pajak baik dari pajak penghasilan, pertambahan nilai maupun cukai. Jika penerimaan pemerintah meningkat, maka akan membawa konsekuensi peningkatan pengeluaran pemerintah. Peningkatan tersebut juga didasari alasan bahwa dengan peningkatan pertumbuhan ekonomi, maka menuntut peningkatan penyediaan barang publik oleh pemerintah. Dengan demikian Wagner's Law berlaku, dimana peningkatan PDRB akan mengakibatkan pengeluaran pemerintah meningkat. Sehingga akan mempunyai efek terhadap peningkatan penerimaan pemerintah.

PAD merupakan pendapatan pendapatan yang menjadi hak untuk dinikmati oleh daerah otonom dari hasil pengelolaan sumber daya yang dimilikinya. Besarnya PAD yang diperoleh mencerminkan daerah tersebut memiliki tingkat pertumbuhan ekonomi yang tinggi. Pendapatan Asli Daerah (PAD) merupakan semua penerimaan daerah yang berasal dari sumber ekonomi asli daerah.

Adapun kelompok Pendapatan Asli Daerah dipisahkan menjadi empat jenis pendapatan, yaitu (Halim, 2001): a) Pajak Daerah merupakan pendapatan daerah yang berasal dari pajak; b) Retribusi Daerah merupakan pendapatan daerah yang berasal dari retribusi daerah; c) Hasil perusahaan milik daerah dan hasil pengelolaan kekayaan milik daerah yang dipisahkan merupakan penerimaan daerah yang berasal dari hasil perusahaan milik daerah dan pengelolaan kekayaan daerah yang dipisahkan; dan d) Pendapatan lain-lain yang sah, di lain pihak adalah penerimaan pemerintah daerah di luar penerimaan-penerimaan dinas, pajak, retribuís dan bagian laba perusahaan daerah. 
Keterkaitan antara PAD dengan belanja modal daerah dapat digambarkan sebagai berikut. Perubahan alokasi belanja ditujukan untuk pembangunan berbagai fasilitas modal. Pemerintah perlu memfasilitasi berbagai aktivitas peningkatan perekonomian, salah satunya dengan membuka kesempatan berinvestasi. Pembangunan infrastruktur dan pemberian berbagai fasilitas kemudahan dilakukan untuk meningkatkan daya tarik investasi. Pembangunan infrastruktur industri mempunyai dampak yang nyata terhadap kenaikan Pendapatan Asli Daerah (PAD). Dengan kata lain, pembangunan berbagai fasilitas ini akan berujung pada peningkatan kemandirian daerah (Wong, 2004 dalam Adi, 2006).

Pendapatan Asli Daerah (PAD) merupakan sumber pendapatan penting bagi sebuah daerah dalam memenuhi belanjanya. Pendapatan Asli Daerah ini sekaligus dapat menujukan tingkat kemandirian suatu daerah. Semakin banyak Pendaptan Asli Daerah yang didapat semakin memungkinkan daerah tersebut untuk memenuhi kebutuhan belanjanya sendiri tanpa harus tergantung pada pemerintah pusat, yang berarti ini menunjukan bahwa Pemerintah Daerah tersebut telah mampu untuk mandiri, dan begitu juga sebaliknya (Rahmawati, 2010).

Hubungan PAD dengan belanja modal daerah tersebut dapat digambarkan dengan teori yang dikemukakan oleh Peacock \& Wiseman (Mangkoesoebroto, 1993; 173). Teori mereka sering disebut sebagai The Displacement Effect, dimana teori ini didasarkan pada suatu pandangan bahwa pemerintah senantiasa memperbesar pengeluaran sedangkan masyarakat tidak suka membayar pajak yang semakin besar untuk membiayai pengeluaran pemerintah yang semakin besar tersebut.
Dalam teori Peacock dan Wiseman terdapat efek penggantian (displacement effect) yaitu adanya gangguan sosial yang menyebabkan aktivitas swasta dialihkan pada aktivitas pemerintah. Pengentasan gangguan tidak hanya cukup dibiayai semata-mata dengan pajak sehingga pemerintah harus meminjam dana dari luar negeri. Setelah gangguan teratasi muncul kewajiban melunasi utang dan membayar bunga. Pengeluaran pemerintah yang semakin bertambah bukan hanya karena GNP bertambah tetapi karena adanya kewajiban baru tersebut. Akibat lebih lanjut adalah pajak tidak menurun kembali ke tingkat semula meskipun gangguan telah berakhir.

Dalam keadaan normal, $\mathrm{t}$ ke $\mathrm{t}+1$, pengeluaran pemerintah dalam persentase terhadap GNP meningkat sebagaimana yang ditunjukan garis AG. Apabila pada tahun $\mathrm{t}$ terjadi perang maka pengeluaran pemerintah meningkat sebesar AC dan kemudian meningkat seperti yang ditunjukan pada segmen CD. Setelah perang selesai pada tahun $t+1$, pengeluaran pemerintah tidak menurun ke G. Hal ini disebabkan setelah perang, pemerintah membutuhkan tambahan dana untuk mengembalikan pinjaman pemerintah yang digunakan dalam pembiayaan pembangunan.

Dana Alokasi Umum (DAU) merupakan salah satu transfer dana Pemerintah kepada pemerintah daerah yang bersumber dari pendapatan APBN, yang dialokasikan dengan tujuan pemerataan kemampuan keuangan antar daerah untuk mendanai kebutuhan daerah dalam rangka pelaksanaan desentralisasi.

Pasal 1 UU RI No. 33 Tahun 2004 tentang Perimbangan Keuangan antara Pemerintah Pusat dan Pemerintahan Daerah menyebutkan bahwa: 
Pengaruh Produk Domestik Regional Bruto... (Hariani Dwi Hartati)

"Dana Alokasi Umum, selanjutnya disebut DAU adalah dana yang bersumber dari pendapatan APBN yang dialokasikan dengan tujuan pemerataan kemampuan keuangan antar daerah untuk mendanai kebutuhan daerah dalam rangka pelaksanaan Desentralisasi”.

Dana Alokasi Umum (DAU) adalah sejumlah dana yang bersumber dari pendapatan APBN yang dialokasikan kepada setiap daerah otonom (provinsi/kabupaten/ kota) di Indonesia setiap tahunnya sebagai dana pembangunan. Dana Alokasi Umum (DAU) bertujuan untuk pemerataan kemampuan keuangan antar daerah yang dimaksudkan untuk mengurangi ketimpangan kemampuan keuangan antar daerah melalui penerapan formula yang mempertimbangkan kebutuhan dan potensi daerah.

Dalam literatur ekonomi dan keuangan daerah, hubungan pendapatan dan belanja daerah didiskusikan secara luas sejak akhir dekade 1950-an dan berbagai hipotesis tentang hubungan diuji secara empiris (Chang \& Ho, 2002). Holtz-Eakin et al (1985) menyatakan bahwa terdapat keterkaitan sangat erat antara transfer dari Pemerintah Pusat dengan belanja pemerintah daerah. Studi Legrensi dan Milas (2001), menggunakan sampel municipalities di Italia, menemukan bukti empiris bahwa dalam jangka panjang transfer berpengaruh terhadap belanja daerah. Secara spesifik mereka menegaskan bahwa variabel-variabel kebijakan pemda dalam jangka pendek disesuaikan (adjusted) dengan transfer yang diterima, sehingga memungkinkan terjadinya respon yang nonlinier dan asymmetric.

Gamkhar dan Oates (1996) menyatakan bahwa pengurangan jumlah transfer (cut in the federal grants) menyebabkan penurunan dalam pengeluaran daerah. Hal tersebut juga tidak berbeda dengan hasil penelitian Sukri \& Halim (2004). Berdasarkan konsep dan temuan-temuan tersebut diatas, maka dapat diduga adanya keterkaitan yang kuat antara DAU tahun berjalan (DAU $U_{t}$ dengan Belanja daerah tahun berjalan $\left(\mathrm{BD}_{\mathrm{t}}\right)$.

Menurut Agency Theory, hubungan kontraktual antara agen (masyarakat) dan prinsipal (pemerintah) dalam konteks DAU dapat dilihat dari bagaimana tanggung jawab pemerintah memberikan pelayanan publik yang baik kepada masyarakat melalui alokasi belanja modal. Hampir sama dengan PAD, DAU merupakan salah satu sumber pembiayaan untuk belanja modal guna pengadaan sarana dan prasarana dalam rangka pemberian pelayanan publik yang baik dari pemerintah daerah kepada masyarakat. Bedanya, kalau PAD berasal dari uang masyarakat sedangkan DAU berasal dari transfer APBN yang dialokasikan dengan tujuan pemerataan keuangan antar daerah untuk membiayai kebutuhan pengeluarannya dalam rangka pelaksanaan desentralisasi.

Berdasarkan hasil penelitian terdahulu dan kajian teori di atas maka kerangka pikir penelitian dapat dikemukakan sebagai berikut:

Megacu pada teori yang dikemukakan oleh Wagner, dikatakan bahwa dalam suatu perekonomian apabila pendapatan per kapita meningkat maka secara relatif pengeluaran pemerintah pun akan meningkat terutama disebabkan karena pemerintah harus mengatur hubungan yang timbul dalam masyarakat, hukum, pendidikan, rekreasi, kebudayaan dan sebagainya (Peters, 2011: $5)$. 
Konsep teori sebagaimana dikemukakan Wagner mengandung implikasi bahwa semakin besar pendapatan yang diperoleh suatu negara atau daerah, maka akan semakin besar pula.

Kinerja keuangan daerah adalah sebagaimana kemampuan pemerintah daerah untuk menghasilkan keuangan daerah melalui penggalian kekayaan asli daerah yang dikatakan sebagai pendapatan asli daerah yang harus terus menerus dipacu pertumbuhannya oleh pemerintah daerah. Jumlah dan kenaikan kontribusi PAD akan sangat berperan dalam kemandirian pemerintah daerah yang dapat dikatakan sebagai kinerja pemerintah daerah (Florida, 2007).

Untuk mengetahui terjadinya peningkatan kemandirian daerah, pendapatan asli daerah bisa dijadikan sebagai tolak ukurnya karena PAD ini sendiri merupakan komponen yang penting yang mencerminkan bagaimana sebuah daerah dapat mendanai sendiri kegiatannya melalui komponen pendapatan yang murni dihasilkan melalui daerah tersebut.

Berdasarkan permasalahan atau latar belakang serta kajian-kajian teoriyang telah dipaparkan diatas, maka penlitian ini bertujuan untuk menganalisis dan mengetahui pengaruh Produk Domestik Regional Bruto (PDRB), Pendapatan Asli Daerah (PAD) dan Dana Alokasi Umum (DAU) terhadap Belanja Modal di Kota Balikapapan baik secara parsial maupun secara simultan. Kemudian akan mencoba menganalisis dan mengetahui variabel yang paling berpengaruh terhadap Belanja Modal di Kota Balikpapan.

\section{Metode Penelitian}

Penelitian ini merupakan penelitian diskriptif data yang di gunakan data sekunder yaitu Laporan Realisasi Anggaran Pen- dapatan dan Belanja Daerah di Kota Balikpapan, data PDRB atas dasar harga konstan menurut Kota Balikpapan, PAD Kota Balikpapan, dan DAU yang diterima Kota Balikpapan selama periode 2002 - 2011. Penelitian ini menganalisis hubungan antara satu variabel dengan variabel lainnya atau bagaimana suatu variabel mempengaruhi variabel yang lain. Variabel dalam penelitian ini terdiri dari 1 (satu) variabel dependen (terikat) berupa belanja modal daerah, dan 3 (tiga) variabel independen (bebas) yang terdiri dari Produk Domestik Regional Bruto (PDRB), Pendapatan Asli Daerah (PAD), dan Dana Alokasi Umum (DAU). Populasi dalam penelitian ini adalah data keuangan pemerintah daerah Kota Balikpapan, yaitu data keuangan berupa Belanja modal daerah, PDRB, PAD, dan DAU, untuk sampelnya adalah Belanja modal daerah, PDRB, PAD, dan DAU selama periode 2002 - 2011, dimana pengambilan sampel dilakukan dengan menggunakan teknik purpossive sampling.

Teknik analisis data yang digunakan dalam penelitian ini yaitu analisis regresi linier berganda dengan 3 prediktor, dimana sebelum melakukan analisis regresi berganda terlebih dahulu dilakukan uji asumsi klasik.

Uji asumsi klasik dilakukan untuk menguji model yang diperoleh dalam penelitian. Setelah model diperoleh, maka harus dilakukan pengujian model untuk mengetahui apakah model yang dihasilkan sudah termasuk BLUE (Best Unbiased Estimator) atau tidak. Model dikatakan BLUE bila memenuhi persyaratan adanya normalitas, linearitas, homoskedastisitas, non autokorelasi dan non-multikolinearitas (Ghozali, 2005: 42). Uji asumsi klasik dalam penelitian ini meliputi uji multikolinearitas, autokorelasi, heteroskedastisitas, normalitas dan linearitas. 
Pengaruh Produk Domestik Regional Bruto... (Hariani Dwi Hartati)

\begin{tabular}{ccccc}
\multicolumn{6}{l}{ Tabel } & \multicolumn{4}{l}{ Hasil Analisis Deskriptif } \\
\hline No. & \multicolumn{1}{l}{ Variabel } & Mean & Median & Std. Deviasi \\
\hline 1. & Belanja Modal & $104.983,11$ & $384.923,11$ & $200.140,16$ \\
2. & PDRB & $28.239 .566,39$ & $27.287 .112,03$ & $11.674 .113,60$ \\
3. & PAD & $96.605,47$ & $71.818,96$ & $72.457,92$ \\
4. & DAU & $157.762,09$ & $148.255,44$ & $48.969,44$ \\
\hline
\end{tabular}

Pengujian hipotesis dalam penelitian ini dilakukan dengan menggunakan analisis regresi linier berganda dengan tiga prediktor. Rumus umumyang digunakan dalam analisis ini adalah sebagai berikut:

$$
\mathrm{Y}_{i}=\beta_{1}+\beta_{2} \mathrm{X}_{2 \mathrm{i}}+\beta_{3} \mathrm{X}_{3 \mathrm{i}}+\beta_{4} \mathrm{X}_{4 \mathrm{i}}+\mathrm{e}
$$

Dimana:

$\mathrm{Y} \quad=$ Belanja Modal Daerah

$\mathrm{b}_{1} \quad=$ Konstanta

$\mathrm{b}_{2,3, \ldots}=$ koefisien regresi

$\mathrm{X}_{1}=$ PDRB

$\mathrm{X}_{2}=\mathrm{PAD}$

$\mathrm{X}_{3}=\mathrm{DAU}$

e $\quad=$ standard of error

(Gujarati, 2005)

\section{Hasil Penelitian dan Pembahasan}

Hasil analisis statistik deskriptif menunjukkan hasil-hasil sebagai berikut:

Hasil tersebut menunjukkan bahwa rata-rata belanja modal Kota Balikpapan periode 2002 - 2011 adalah sebesar Rp. 104.983 milyar. Rata-rata PDRB adalah sebesar Rp.28,239 trilyun. Rata-rata PAD adalah sebesar Rp. 96,605 milyar. Ratarata DAU adalah sebesar Rp. 157,762 milyar.

Asumsi-asumsi regresi yang harus dipenuhi agar estimasi yang diperoleh bersifat BLUE (Best, Linear, Unbiased, Estimator) meliputi: 1) model regresi merupakan hubungan linear dalam parameter, 2) tidak ada multikolinearitas, 3 ) variabel $\mathrm{X}$ harus memiliki variabilitas, 4) homoskedastisitas, 5) non-auto-korelasi.

Hasil analisis menunjukkan bahwa semua asumsi sudah terpenuhi. Dengan demikian maka analisis selanjutnya dapat dilakukan.

Pembuktikan kebenaran hipotesis dilakukan menggunakan uji regresi linier berganda dengan tiga prediktor. Uji statistik regresi linier berganda yang dilakukan meliputi: Uji ketepatan parameter (t test), Uji ketepatan model (F test) dan koefisien determinasi $\left(\mathrm{R}^{2}\right)$.

Hasil pengujian regresi linier dapat diringkaskan ke dalam tabel berikut ini:

Tabel 2. Ringkasan Hasil Analisis Regresi

\begin{tabular}{lcccc}
\hline & Variabel & Parameter & $\mathrm{t}$ & $\mathrm{P}$ \\
& & & statistik \\
& & & & \\
\hline a. & Konstanta & -12.444 & -2.346 & 0.057 \\
b. & PDRB & 1.415 & 3.916 & 0.008 \\
c. & PAD & -0.544 & -1.765 & 0.128 \\
d. & DAU & 0.608 & 1.998 & 0.093 \\
R & $=0.908$ & $\mathrm{R}^{2}=0.824$ & \\
F & $=9.370$ & & & \\
p & $=0.011$ & & &
\end{tabular}

Berdasarkan hasil-hasil perolehan uji regresi pada tabel2, dapat diketahui bahwa persamaan regresi yang diperoleh dalam penelitian ini adalah sebagai berikut:

$\operatorname{Ln} \hat{Y}=-12.444+1,415 \operatorname{Ln} X_{1}-0,544 \operatorname{Ln}$

$$
\mathrm{X}_{2}+0,608 \operatorname{Ln} \mathrm{X}_{3}+\mathrm{e}
$$

Persamaan tersebut dapat diartikan bahwa apabila nilai-nilai $X_{1}, X_{2}, X_{3}$ dianggap konstan maka belanja modal daerah Kota 
Balikpapan adalah sebesar 12,444. Tanda positif (+) pada variabel $X_{1}$ dan $X_{3}$ menunjukkan arah searah, artinya apabila PDRB dan DAU meningkat maka belanja modal akan meningkat pula, begitu pula sebaliknya. PAD menunjukkan tidak berkontribusi signifikan sehingga tidak dapat dijelaskan.

Hasil pengujian menunjukkan bahwa nilai statistik $F$ diperoleh sebesar 9,370 dengan signifikansi $p=0,011$. Mengingat nilai signifikansi $\mathrm{p}<0,05$ maka $\mathrm{H}_{0}$ ditolak dan Ha diterima. Dengan demikian maka dapat disimpulkan bahwa variabel-variabel $\operatorname{PDRB}\left(\mathrm{X}_{1}\right)$, PAD $\left(\mathrm{X}_{2}\right)$, dan DAU $\left(\mathrm{X}_{3}\right)$ secara bersama-sama berpengaruh signifikan terhadap Belanja Modal Daerah (Y) di Kota Balikpapan.

Hasil pengujian menunjukkan bahwa nilai koefisien determinasi (adjusted $\mathrm{R}^{2}$ ) diperoleh sebesar 0,824. Hal ini menunjukkan bahwa PDRB $\left(\mathrm{X}_{1}\right)$, PAD $\left(\mathrm{X}_{2}\right)$, dan DAU $\left(\mathrm{X}_{3}\right)$ secara bersama-sama menentukan variabilitas Belanja Modal Daerah (Y) di Kota Balikpapan sebesar 82,4\%. Sisanya sebesar $17,6 \%$ diberikan oleh variabel lain di luar model ini.

Hasil analisis uji ketepatan parameter penduga untuk variabel PDRB $\left(\mathrm{X}_{1}\right)$ terhadap Belaja Modal (Y) diperoleh nilai t statistik sebesar 3,916 dengan signifikansi $\mathrm{p}=0,008$. Mengingat nilai signifikansi $\mathrm{p}<$ 0,05 maka $\mathrm{H}_{0}$ ditolak dan Ha diterima. Dengan demikian maka dapat disimpulkan bahwa PDRB $\left(\mathrm{X}_{1}\right)$ secara parsial berpengaruh signifikan terhadap Belanja Modal Daerah (Y) di Kota Balikpapan. Berdasarkan hasil tersebut, maka hipotesis yang menyatakan bahwa PDRB $\left(\mathrm{X}_{1}\right)$ secara parsial berpengaruh signifikan terhadap Belanja Modal Daerah (Y) di Kota Balikpapan terbukti kebenarannya.
Besarnya pengaruh yang diberikan PDRB $\left(X_{1}\right)$ terhadap Belanja Modal Daerah (Y) dapat dihitung dengan nilai beta yang diperoleh dibagi dengan jumlah nilai beta ketiga variabel bebas kemudian dikalikan dengan koefisien determinasinya. Hasil perhitungan menunjukkan bahwa pengaruh yang diberikan PDRB $\left(\mathrm{X}_{1}\right)$ terhadap Belanja Modal Daerah (Y) adalah sebesar 45.42\%.

Hasil analisis uji ketepatan parameter penduga untuk variabel PAD $\left(\mathrm{X}_{2}\right)$ terhadap Belaja Modal (Y) diperoleh nilai t statistik sebesar $-1,765$ dengan signifikansi $\mathrm{p}=$ 0,128 . Mengingat nilai signifikansi $p>0,05$ maka $\mathrm{H}_{0}$ diterima dan Ha ditolak. Dengan demikian maka dapat disimpulkan bahwa $\operatorname{PAD}\left(\mathrm{X}_{2}\right)$ secara parsial tidak berpengaruh signifikan terhadap Belanja Modal Daerah (Y) di Kota Balikpapan. Berdasarkan hasil tersebut, maka hipotesis yang menyatakan bahwa PAD $\left(\mathrm{X}_{2}\right)$ secara parsial berpengaruh signifikan terhadap Belanja Modal Daerah (Y) di Kota Balikpapan tidak terbukti kebenarannya.

Hasil analisis uji ketepatan parameter penduga untuk variabel DAU $\left(\mathrm{X}_{3}\right)$ terhadap Belaja Modal (Y) diperoleh nilai t statistik sebesar 1,998 dengan signifikansi $\mathrm{p}=$ 0,093 . Mengingat nilai signifikansi $p>0,05$ maka $\mathrm{H}_{0}$ diterima dan Ha ditolak. Dengan demikian maka dapat disimpulkan bahwa DAU $\left(\mathrm{X}_{3}\right)$ secara parsial tidak berpengaruh signifikan terhadap Belanja Modal Daerah (Y) di Kota Balikpapan. Berdasarkan hasil tersebut, maka hipotesis yang menyatakan bahwa DAU $\left(\mathrm{X}_{3}\right)$ secara parsial berpengaruh signifikan terhadap Belanja Modal Daerah (Y) di Kota Balikpapan tidak terbukti kebenarannya.

Hasil penelitian menunjukkan bahwa Produk Domestik Regional Bruto (PDRB), Pendapatan Asli Daerah (PAD) dan Dana 
Alokasi Umum (DAU) secara simultan berpengaruh signifikan terhadap Belanja Modal di Kota Balikpapan. Hal ini ditunjukkan dengan perolehan hasil uji F statistik di mana diperoleh nilai $F$ statistik sebesar 9.370 yang signifikan pada $\alpha=0.05$. Besarnya pengaruh yang diberikan ketiga variabel tersebut secara bersama-ditunjukkan dengan besarnya koefisien determinasi $\left(\mathrm{R}^{2}\right)$ yang dihasilkan, yaitu 0.824. Dengan demikian maka dapat diartikan bahwa ketiga variabel bebas dalam penelitian mampu menentukan variabilitas belanja modal daerah Kota Balikpapan sebesar 82.4\%. Sisanya sebesar $17.6 \%$ ditentukan oleh variabel lain di luar model ini.

Hasil penelitian menunjukkan bahwa rasio besaran belanja modal daerah terhadap total belanja daerah di Kota Balikpapan selama periode 2002-2011 secara rata-rata adalah sebesar $37.11 \%$. Temuan tersebut mengindikasikan bahwa pemerintah Kota Balikpapan sudah memenuhi amanat yang terkandung dalam Permendagri Nomor 27 Tahun 2013 tersebut.

Hasil penelitian bahwa Produk Domestik Regional Bruto (PDRB), Pendapatan Asli Daerah (PAD) dan Dana Alokasi Umum (DAU) secara simultan berpengaruh signifikan terhadap Belanja Modal di Kota Balikpapan konsisten dengan hasil penelitian yang dilakukan oleh Askam Tuasikal (2008) di mana DAU, DAK, PAD dan PDRB baik simultan maupun parsial berpengaruh terhadap Belanja Modal.

Ditinjau dari pengaruh secara parsial, hasil penelitian menunjukkan bahwa variabel yang berpengaruh signifikan terhadap belanja modal daerah di Kota Balikpapan selama periode 2002 - 2011 hanyalah PDRB, yang ditunjukkan dengan nilait statistik yang signifikan pada $\alpha=5 \%$. Adapun kedua variabel lainnya, yaitu PAD dan DAU tidak berpengaruh signifikan secara statistik, yang ditunjukkan dengan nilait statistik yang tidak signifikan pada $\alpha=5 \%$.

Temuan ini konsisten dengan hasil penelitian yang dilakukan oleh Askam Tuasikal (2008), dan Farah Marta Yovita (2011). Kedua peneliti tersebut memperoleh hasil bahwa PDRB berpengaruh signifikan terhadap belanja modal, sedangkan PAD dan DAU tidak berpengaruh signifikan terhadap belanja modal daerah. Hal ini dapat dipahami bahwa pada daerah dengan PDRB yang besar, seperti Kota Balikpapan, tingkat ketergantungan kepada pemerintah pusat dalam penganggaran tidak terlalu signifikan.

Temuan bahwa PDRB berpengaruh signifikan terhadap belanja modal daerah konsisten dengan hasil penelitian yang dilakukan oleh Bataineh (2012), danAlexiou (2009). Kedua peneliti tersebut memperoleh temuan bahwa pembelanjaan pemerintah berpengaruh positif terhadap pertumbuhan GDP yang sesuai dengan teori Keynesian.

Temuan ini bertolak belakang dengan hasil penelitian yang dilakukan oleh Ikin Solikin (2007), Nugroho Suratno Putro (2011), dan Rini Oktriniatmaja (2012). Ketiga peneliti tersebut menghasilkan temuan bahwa PAD, DAU, DAK berpengaruh positif terhadap Belanja Modal baik secara parsial maupun simultan, sementara Pertumbuhan Ekonomi tidak berpengaruh terhadap Belanja Modal. Hasil yang tidak konsisten tersebut dapat dipahami mengingat peneliti-peneliti tersebut meneliti daerah yang masihmempunyai ketergantungan yang tinggi terhadap transfer pemerintah pusat dalam mendukung APBD mereka. 
Hasil penelitian menunjukkan bahwa besaran PAD terhadap total pendapatan daerah di Kota Balikpapan selama periode 2002 - 2011 secara rata-rata adalah sebesar $10.31 \%$. Hal ini diartikan bahwa PAD hanya memberikan sumbangan ratarata sebesar $10.31 \%$ terhadap total pendapatan daerah. Sumbangan yang diberikan DAU terhadap total pendapatan daerah di Kota Balikpapan selama periode 2002 2011 secara rata-rata adalah sebesar $19.97 \%$.

Penggabungkan kedua jenis pendapatan tersebut baru mencapai proporsi sekitar 31\% dari total pendapatan daerah Kota Balikpapan. Hal ini dapat diartikan bahwa proporsi terbesar dari pendapatan yang diperoleh Kota Balikpapan berasal dari pendapatan lain yang syah. Kondisi tersebut menunjukkan bahwa Kota Balikpapan sudah sangat siap dalam melaksanakan desentralisasi.

Hasil penelitian menunjukkan bahwa PDRB merupakan variabel yang mempunyai pengaruh paling dominan terhadap belanja modal di Kota Balikpapan periode 2002 2011 di antara variabel-variabel Produk Domestik Regional Bruto (PDRB), Pendapatan Asli Daerah (PAD) dan Dana Alokasi Umum(DAU). Hal ini ditunjukkan dengan nilai beta yang dihasilkan variabel ini dalam persamaan regresi merupakan nilai terbesar dibandingkan dengan nilai beta yang dihasilkan oleh variabel-variabel lainnya. Sumbangan efektifPDRB terhadap belanja modal daerah Kota Balikpapan adalah sebesar $45.42 \%$.

Hasil tersebut cukup beralasan mengingat perekonomian Kota Balikpapan sebagian besar terbentuk dari Nilai Tambah Bruto (NTB) yang tercipta dalam suatu region atau lebih dikenal dengan nama Produk Domestik Regional Bruto (PDRB ). PDRB
Kota Balikpapan disajikan dalam dua pendekatan, dengan migas maupun tanpa migas yang dihitung menurut harga berlaku maupun harga konstan.

Pertumbuhan PDRB Kota Balikpapan (dengan migas) tahun 2011 mencapai $8,57 \%$, melambat terhadap tahun sebelumnya, yang mencapai $11.48 \%$. Selama kurun waktu sepuluh tahun terakhir (tahun 2002 - 2011) secara kumulatif pertumbuhan ekonomi (dengan Migas) 70,33\% dan dengan rata - rata kenaikan sebesar $7,81 \%$ per tahun. Berdasarkan hal tersebut maka secara logis dapat dipahami bahwa PDRB merupakan variabel yang mempunyai pengaruh dominan terhadap alokasi belanja modal daerah Kota Balikpapan.

\section{Penutup}

Kesimpulan yang dapat dambil dari pembahasan di atas adalah: Pertama, Produk Domestik Regional Bruto (PDRB), Pendapatan Asli Daerah (PAD) dan Dana Alokasi Umum (DAU) berpengaruh terhadap Belanja Modal di Kota Balikpapan baik secara parsial maupun secara simultan. a) Produk Domestik Regional Bruto (PDRB), Pendapatan Asli Daerah (PAD) dan Dana Alokasi Umum (DAU) secara bersama-sama berpengaruh signifikan terhadap Belanja Modal di Kota Balikpapan. Hal ini ditunjukkan dengan perolehan hasil uji F statistik di mana diperoleh nilai $F$ statistik sebesar 9.370 yang signifikan pada $\alpha=0.05$. Besarnya pengaruh yang diberikan ketiga variabel tersebut secara bersama-ditunjukkan dengan besarnya koefisien determinasi $\left(\mathrm{R}^{2}\right)$ yang dihasilkan, yaitu 0.824. Dengan demikian maka dapat diartikan bahwa ketiga variabel bebas dalam penelitian mampu menentukan variabilitas belanja modal daerah Kota Balikpapan sebesar $82.4 \%$. Sisanya sebesar 
Pengaruh Produk Domestik Regional Bruto... (Hariani Dwi Hartati)

$17.6 \%$ ditentukan oleh variabel lain di luar model ini; b) Produk Domestik Regional Bruto (PDRB) secara parsial berpengaruh signifikan terhadap Belanja Modal di Kota Balikpapan. Hal ini ditunjukkan dengan perolehan nilait statistik sebesar 3,916 yang signifikan pada $\alpha=0,05$. Pengaruh yang diberikan PDRB $\left(\mathrm{X}_{1}\right)$ terhadap Belanja Modal Daerah (Y) Kota Balikpapan secara parsial adalah sebesar 45.42\%; c) Pendapatan Asli Daerah (PAD) secara parsial tidak berpengaruh signifikan terhadap Belanja Modal di Kota Balikpapan. Hal ini ditunjukkan dengan perolehan nilait statistik sebesar -1,765 yang tidak signifikan pada $\alpha=0,05$; d) Dana Alokasi Umum (DAU) secara parsial tidak berpengaruh signifikan terhadap Belanja Modal di Kota Balikpapan. Hal ini ditunjukkan dengan perolehan nilai $\mathrm{t}$ statistik sebesar 1,998 yang tidak signifikan pada $?=0,05$.

Kedua, Variabel Produk Domestik Regional Bruto (PDRB) merupakan variabel yang paling berpengaruh terhadap Belanja Modal di Kota Balikpapan di antara Produk Domestik Regional Bruto (PDRB), Pendapatan Asli Daerah (PAD) dan Dana Alokasi Umum(DAU). Hal ini ditunjukkan dengan nilai beta yang dihasilkan variabel ini dalam persamaan regresi merupakan nilai terbesar dibandingkan dengan nilai beta yang dihasilkan oleh variabel-variabel lainnya. Sumbangan efektifPDRB terhadap belanja modal daerah Kota Balikpapan adalah sebesar $45.42 \%$.

\section{DAFTAR PUSTAKA}

Badan Pemeriksa Keuangan. 1976. Petunjuk Pelaksanaan Tuntutan Perbendaharaan dan Tuntutan Ganti Rugi. BPK. Jakarta.
Chang, Tsangyao \& Yuan Hong Ho. 2002. Tax or spend, what cause what: Taiwan's experience . International Journal of Business and economics 1 (2): 157-165.

Darise, Nurlan. 2006. Pengelolaan Keuangan Daerah. Penerbit PT Indeks. Jakarta.

Dian Puji N. Simatupang. 2005.Determinasi Kebijakan Anggaran Negara Indonesia, Studi Yuridis. Papas Sinar

Sinanti. Jakarta.

Gamkhar, Shama \& Wallace Oates. 1996. Asymetries in response to increase And decrease in intergovernmental grants: Some empirical findings. National Tax Journal 49 (4):501-512.

Ghozali, Imam. 2006. Aplikasi Analisis Multivariate Dengan Program SPSS. BP UNDIP. Semarang.

Gujarati, Damodar. 2005. Ekonometrika Dasar, Alih Bahasa Sumano Zain. Penerbit Erlangga. Jakarta.

Halim, Abdul. 2001. Anggaran daerah dan "fiscal stress" (sebuah studi kasus pada Anggaran daerah provinsi di Indonesia). Jurnal Ekonomi dan Bisnis Indonesia 16(4): 346-357.

Holtz-Eakin, Douglas, Harvey S. Rosen, \& Schuyler Tilly. 1994. Intertemporal Analysis of state in local government spending: Theory and test. Journal $O f$ Urban Economics 35: 159-174.

Jacobs, Davina F. 2009. "Capital Expenditures and the Budget". IMF, PFM Technical Guidance Note No. 8, pp: 1-13, http://www.proquest.umi.com diakses pada 2 Januari 2014. 
Mohammed Al Bataineh, Ibrahem. 2012.

"The Impact of Government Expenditures on Economic Growth in Jordan". Interdisciplinary Journal of Contemporary Research in Business Vol. 4 No. 6, October 2012, http:// www.proquest.umi.com diakses pada 20 Nopember 2013.

Prasetya, Ferry. 2012. Modul Ekonomi Publik, Bagian V: Teori Pengeluaran Pemerintah. Universitas Brawijaya. Malang.

Sekaran, Uma. 2002. Research Methods for Business. John Wiley \& Sons, Inc. New York.

Suhandak, Nugroho Trilaksono. 2007. Paradigma Baru Pengelolaan Keuangan Daerah Dalam Penyuisunan APBD di Era Otonomi. FIA-UNIBRAW Malang dengan Bayumedia Publishing.

Sulaiman, Anwar. 2000. Manajemen Aset Daerah. STIA-LAN. Jakarta.

Yani, Ahmad. 2004. Hubungan Keuangan Antara Pemerintah Pusat Dan Daerah di Indonesia (Cetakan kedua). PT Raja Grafindo Persada. Jakarta. 